\title{
A NEW FOSSIL MOSS FROM THE LOWER PERMIAN \\ OF THE RUSSIAN FAR EAST
}

\section{НОВЫЙ ИСКОПАЕМЫЙ МОХ ИЗ НИЖНЕПЕРМСКИХ ОТЛОЖЕНИЙ РОССИЙСКОГО ДАЛЬНЕГО ВОСТОКА}

\author{
MiCHAEL S. IGNATOV ${ }^{1} \&$ DMITRY E. SHCHERBAKOV ${ }^{2}$ \\ МИХАИЛ С. ИГНАТОВ ${ }^{1}$, ДМИТРИЙ Е. ЩЕРБАКОВ ${ }^{2}$
}

\begin{abstract}
A new genus and species Palaeocampylopus buragoae is described by imprints in the Lower Permian deposits from the Russky Island in the Sea of Japan, the Russian Far East. The plant size and the overall habit, orthotropic growth, narrow leaves, and especially terminal cup-like structures, resembling rosettes of perigonial leaves, indicate the most probable affinity with Dicranaceae (cf. Campylopus) or Polytrichaceae (cf. Polytrichum and Polytrichastrum). The costa is unseen in leaves and likely was very broad. Although the cell structure is not well seen, striation of abaxial costa surface allows to estimate the width of dorsal epidermal cells.
\end{abstract}

Резюме

Из отложений нижней перми с острова Русский (Японское море, российский Дальний Восток) описан новый вид и род, Palaeocampylopus buragoae. Он похож на современные виды Dicranaceae (например, Campylopus) и Polytrichaceae (например, Polytrichum и Polytrichastrum) по размерам и общему габитусу растений, прямостоячему росту, узким листьям, и, особенно, по чашевидным структурам на верхушках побегов, которые весьма сходны с собраниями перигониальных листьев мужских растений указанных родов. Жилка на отпечатках листа не выделяется, что, очевидно, свидетельствует в пользу того, что она занимала практически всю ширину листа. Хотя клеточная структура в целом не видна, продольная исчерченность жилки позволяет сделать заключение о ширине клеток ее дорсального эпидермиса.

KEYWORDS: Palaeocampylopus, Bryophyta, fossils, Permian, Russian Far East, Polytrichaceae, Dicranaceae

\section{INTRODUCTION}

Despite the common belief that mosses are an ancient group of plants, the paleobotany does not fully support this statement. There is no one Devonian record, and Carboniferous mosses are extremely few (Renault \& Zeiller, 1885, 1888; Lignier, 1914; Thomas, 1972), and none of them allows complete enough restoration of plants. In the Permian, however, mosses became much more common in Angaraland (Neuburg, 1960; Fefilova, 1978), Eurameria (Gomankov \& Meyen,
1987; Ignatov, 1990), and two earliest records from Gondwanaland belong to this period as well (Townrow, 1959; Smoot \& Taylor, 1986). Angarian material in many collections is preserved well enough for studying cell structure of leaves that is an important character for moss taxonomy. Only gametophytic remains are known up to now and all of them represent sterile plants, with one exception of the genus Protoochyraea, where one leaf fragment may represent a perigonial bract (Ignatov, 1990).

1 - Main Botanical Garden, Russian Academy of Sciences, Botanicheskaya 4, Moscow 127276 Russia, e-mail: misha_ignatov@list.ru

2 - Paleontological Institute, Russian Academy of Sciences, Profsoyuznaya 123, Moscow 117997 Russia, email: dshh@narod.ru 
Collecting fossil insects in the Russky Island of the Sea of Japan in 2008, the second author found a slab with interesting imprints resembling modern male plants of Polytrichum and Campylopus, and they are described here as a new genus Palaeocampylopus.

\section{MATERIAL AND LOCALITY}

The moss imprints were found on the surface of black coaly shales (containing abundant plant fossils, Bivalvia and few Conchostraca) of the lower subformation of the Pospelovo Formation, cropping out in the coastal cliff $0.3 \mathrm{~km} \mathrm{SSW}$ of the Cape Novosilsky, the Russky Island near Vladivostok.

This subformation is dated Middle Kungurian (ca. $273 \mathrm{Ma}$ ) according to the International Stratigraphic Scale (Zakharov et al., 2009; corresponds to Late Kungurian of the East European Stratigraphic Scale).

The diverse vascular flora of the lower Pospelovo Formation is of the Siberian type, consists of sphenopsids, ferns, and Angaran cordaites and lacks undoubted pteridosperms and Cathaysian elements (Tashchi \& Burago, 1974; Zimina, 1977, 1997; Zakharov et al., 2009). This plant assemblage is similar to those from the Rudnik Subformation (the Lek-Vorkuta Formation, Vorkuta Group, the Kungurian or the Ufimian) of the Pechora Basin and from the Usa and Starokuznetsk Formations (the Kuznetsk Subgroup) of the Kuznetsk Basin (Kotlyar et al., 2006). Abundant mosses (including Intia sp.: V.I. Burago in Meyen, 1982, and pers.comm.) and liverworts are recorded.

The Russky Island belongs to the Bureya-Jiamusi-Khanka block at the east of the Amuria microcontinent. In the Permian it was situated at the eastern margin of Asia. According to paleomagnetic data, Amuria had accreted to the North China block by the Late Carboniferous, but had not been sutured to Siberia until the Late Jurassic (see Hankard et al., 2007). Basing on wide occurrence of the Siberian-type flora and the high boreal marine fauna in Amuria, some authors suggested that, in the Permian, the latter block was situated closer to Siberia (Rees et al., 1999; Chumakov \& Zharkov, 2002). Other researchers explain these facts by global climatic oscillations rather than significant drift of the terranes, and consider the lower Pospelovo time belonging to one of the coldest intervals (Markevich \& $\mathrm{Za}$ kharov, 2008; Zakharov et al., 2009).

\section{CHARACTERISTICS OF COLLECTIONS}

The collection consists of three slabs $(5-6 \times 3-$ $4 \mathrm{~cm}$ ) with imprints (PIN ${ }^{1}$ no.5328/1, 2, 3), one of them with counterpart, and 3 smaller slabs (PIN no.5328/4, 5, 6), one with counterpart. One slab, PIN no. 5328/1 (Fig. 1) has shoots which are more or less spaced and rather well visible, and some of them have cup-like structures on the shoots tops. Two others, 5328/2 \& 5328/3, have imprints of sterile leafy shoots many of which strongly overlay each other and are not so clearly seen (Figs. 11-14) and in general are slightly smaller than the shoots in Fig. 1 (cf. also Fig. 16).

Four terminal cup-like structures are clearly visible (Fig. 1) on stems tops (A, B, C, E), and one more $(\mathrm{F})$ is seen without any connection to stems. Cup-like structures are less flattened comparing to the rest of the shoots and rise above the overall surface of imprint (and correspondingly lower in the counterpart). This may indicate that their texture was more rigid or the content inside them was more solid. The specimen shown in Fig. 17 is only tentatively referred to the species described here; it is also ascribed to have a perigonial structure, which is, however, unapparent, as will be discussed below.

Shoots bearing cup-like structures are rather loosely foliate, the leaves having lanceolate proximal portion and subulate acumen. Differences in foliage density obviously indicate that not all leaves are preserved or exposed on the rock surface, and for many of them only the proximal part is seen.

Leaves on different shoots have certain differences in shape, but the present material does not allow to sort them out into several distinct types. We are inclined to consider these differences as an infraspecific (or even infraindividual) variation, assuming: (1) variation within separate shoots (Figs. 6-16); (2) intermixed growth; (3) variation pattern in superficially similar extant mosses, e.g. Dicranum and Campylopus species. Concerning this variation, an important point would be that the upper leaves in many species have longer and narrower lamina with a subulate distal part. In Dicranaceae, Polytrichaceae and

1_Paleontological Institute, Russian Academy of Sciences 


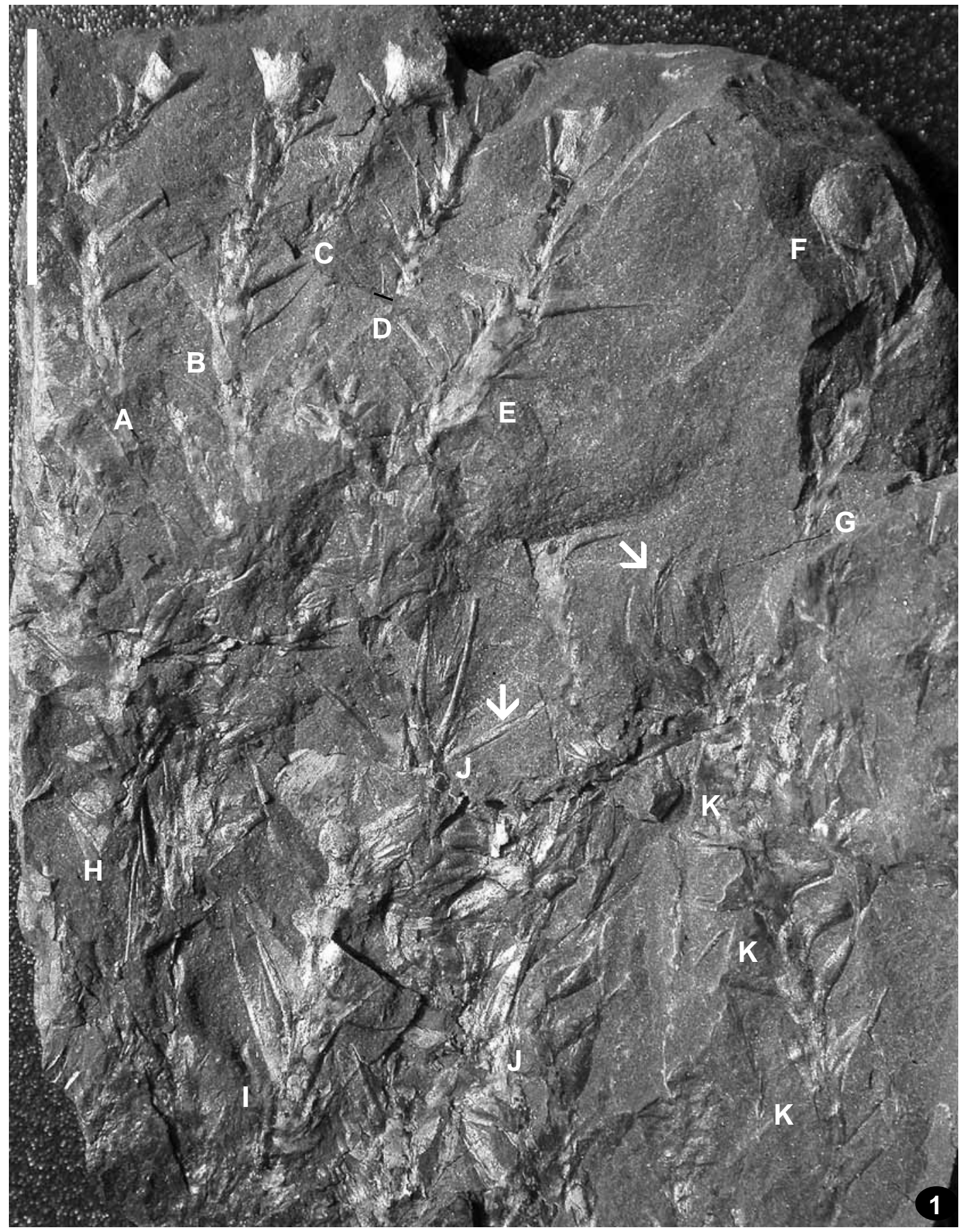

Fig. 1. Palaeocampylopus buragoae Ignatov \& Shcherbakov (from PIN no. 5328/1; letters upon picture: B holotype; A and C-K other shoots). Shoots A, B, C, E represent plants terminated with putative perigonia, and F is interpreted as isolated perigonium (by resemblance with those of specimens $\mathrm{A}-\mathrm{C}, \mathrm{E}$ ); plants $\mathrm{D}, \mathrm{I}-\mathrm{K}$ have no perigonialike structures, but their distal leaves are longer and distally subulate. Shoot K has above the terminal cluster of narrow leaves on almost leafless axis (oblique arrow), which immediate connection however not apparent. Shoot G, $\mathrm{H}$ and some smaller remnants are poorly preserved, although solitary leaves indicate that they likely belong to the same species. Vertical arrow points the leaf shown at higher magnification in Fig. 15. Scale bar $10 \mathrm{~mm}$. 

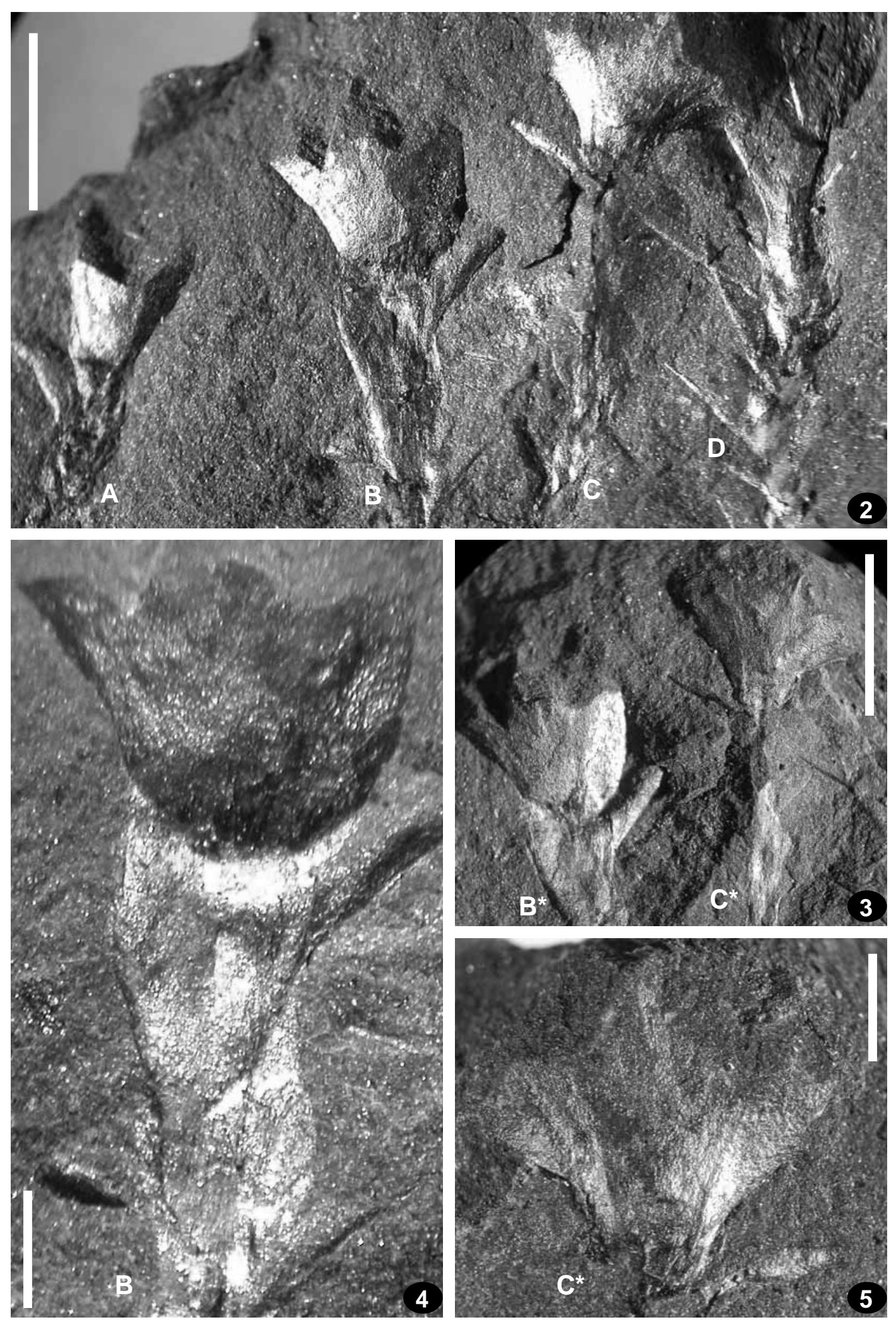

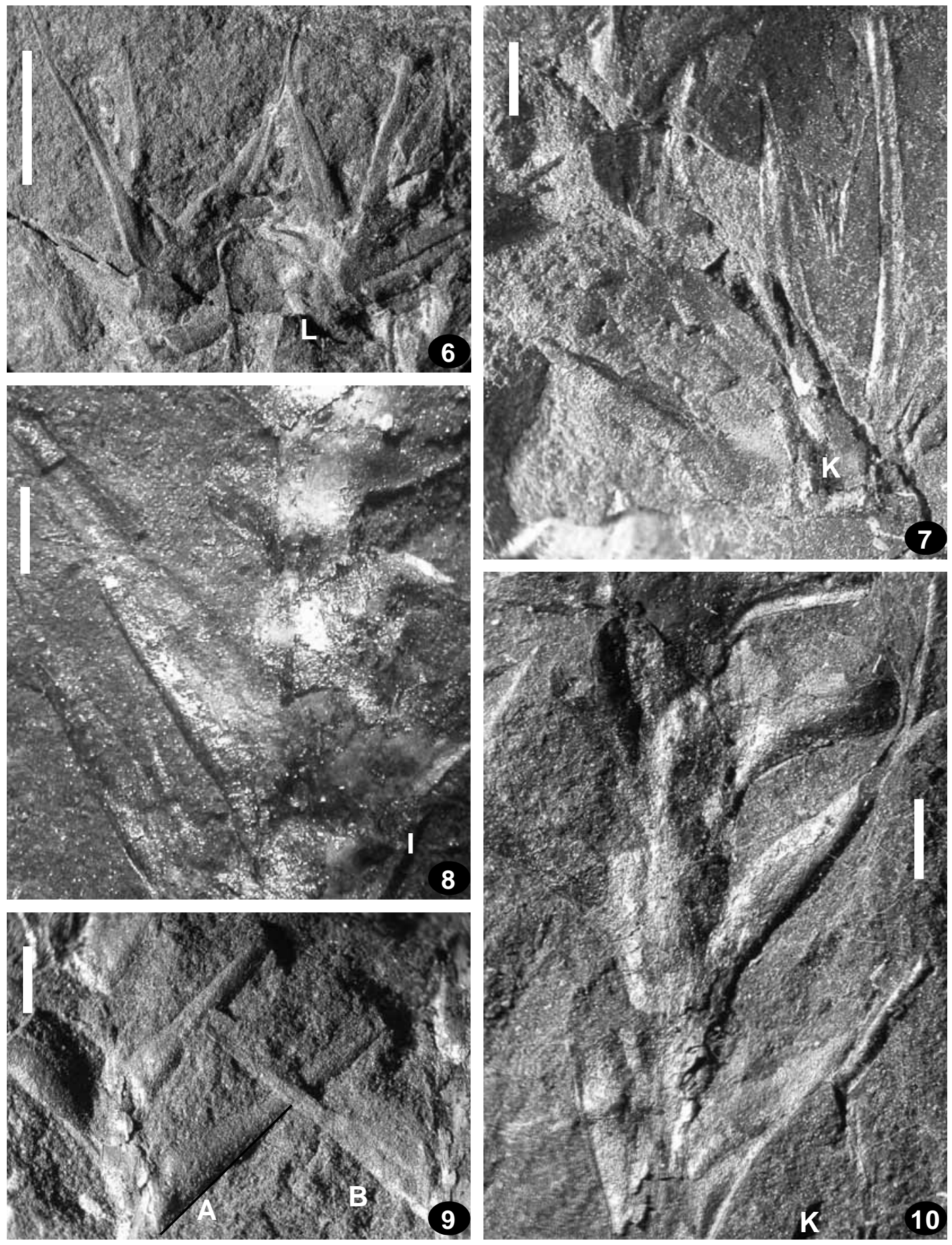

Figs. 6-10. Shoots of Palaeocampylopus buragoae Ignatov \& Shcherbakov, showing leaf shape variation (6 - from PIN no. 5328/3; 7-10 from no. 5328/1); 6 and 7 represent foliage near shoot tops; 8-10 - foliage in middle part of shoots. Letters upon pictures are the same as in Fig. 1; Scale bars $3 \mathrm{~mm}$ for 6; $1 \mathrm{~mm}$ for 7-10.

Figs. 2-5 (opposite page). Putative perigonia of Palaeocampylopus buragoae Ignatov \& Shcherbakov (from PIN no. 5328/1; letters upon pictures are the same as in Fig. 1, including B - holotype; $\mathrm{B}^{*}$ - counterpart of holotype; $\mathrm{C}^{*}$ is counterpart of C). Scale bars $3 \mathrm{~mm}$ for 2-3; $1 \mathrm{~mm}$ for 4-5. [Fig. 3 is horizontally flipped]. 

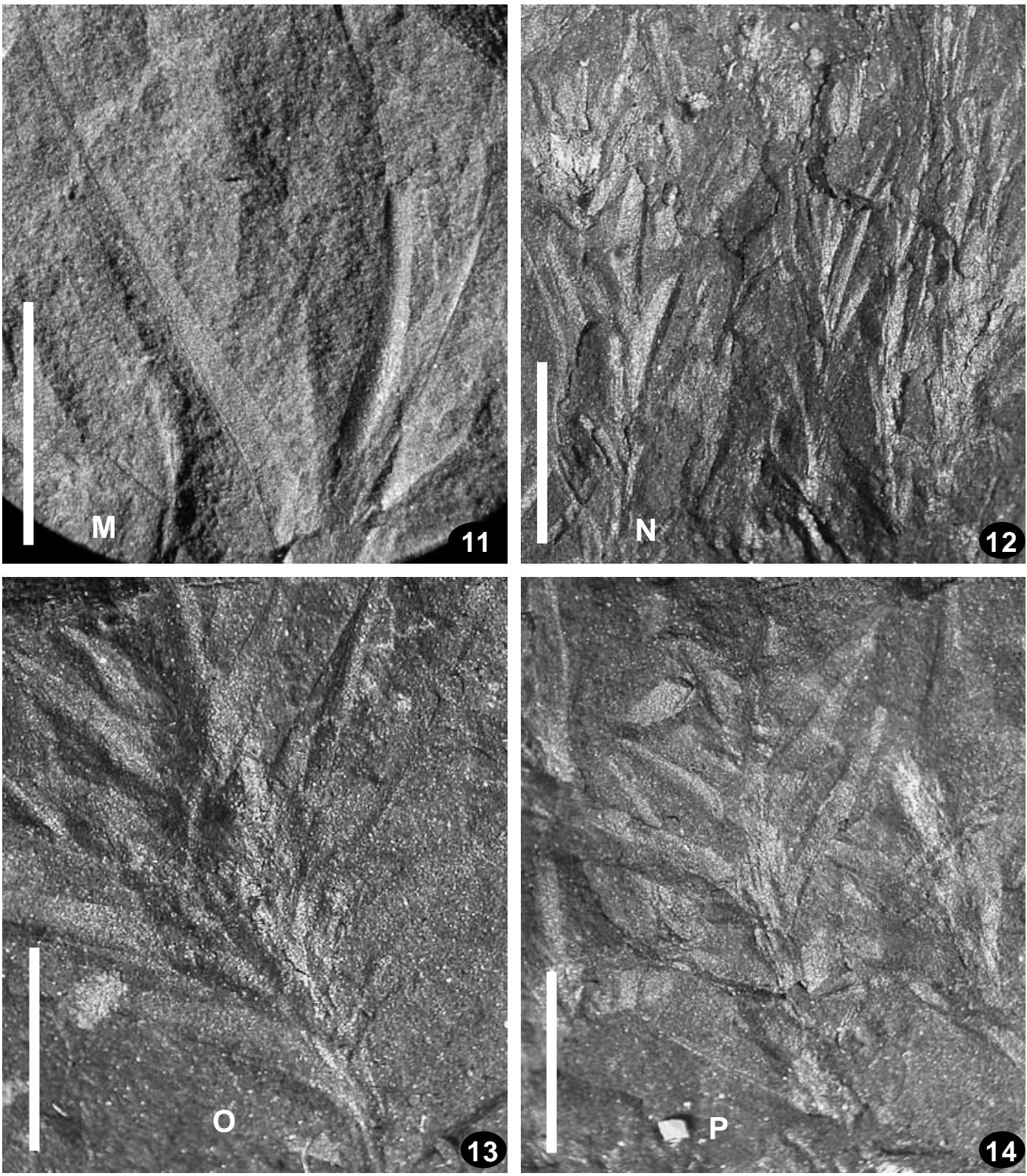

Figs. 11-14. Shoots of Palaeocampylopus buragoae Ignatov \& Shcherbakov, showing leaf shape variation (from PIN no. 5328/2). Letters M-P upon pictures correspond those in Fig. 16. Scale bars $3 \mathrm{~mm}$.

most of other moss families perichaetial leaves (around female gametangia) are longer and narrower than vegetative leaves, whereas perigonial leaves (around male gametangia) are shorter. Correspondingly there is a tendency for vegetative leaves to elongate near perichaetial, but not near perigonial leaves.

Assuming this albeit indirect evidence, we may speculate that the cup-like terminal structures are perigonial leaves, and therefore plants with them are male ones. At the same time, stems terminating with longer leaves with a subulate upper portion are likely to be female. Although hypothetical, this assumption may be helpful at least for the circumscription of the present material.

The longest "female" shoot ( $\mathrm{K}$ in Fig. 1) is $25 \mathrm{~mm}$ long, while the longest "male" shoot (B in Fig. 1) is $18 \mathrm{~mm}$. Most of the shoots range 


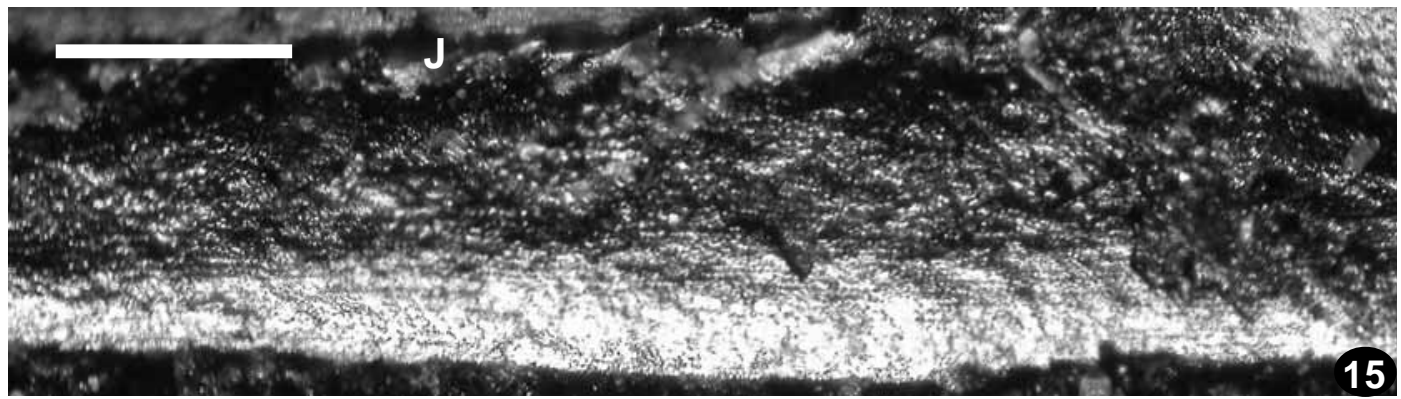

Figs. 15. Leaf of Palaeocampylopus buragoae Ignatov \& Shcherbakov, showing longitudinal striation, likely indicating the width of cells of dorsal epidermis (from PIN no. 5328/1; leaf in upper part of shoot J in Fig. 1 (marked in Fig. 1 by vertical arrow). Scale bar $300 \mu \mathrm{m}$.

from 10 to $15 \mathrm{~mm}$ long. Stem width in compressions together with leaf bases is $0.9-1.2 \mathrm{~mm}$.

Leaves are arranged in a dense spiral typical for mosses. They are erect (Fig. 12) to patent (Figs. 8-10), the former being restricted to smaller plants in dense growth that may be interpreted as younger plants (although the alternative suggestion that they belong to another taxon would be difficult to contest). The angle with the stem in many cases is about $70^{\circ}$; individual leaves in the cluster of upper leaves deviate to ca. $110^{\circ}$, but their position may be considered as an artifact of fossilization. Maximal leaf length is $9 \mathrm{~mm}$ (found in 2 leaves) and this is not the total length, as the leaf tips look incompletely preserved. In few cases rock surface above a putatively broken leaf apex has some thin filiform traces 1-2 mm long, but they are never clear enough to make certain that they belong to a given leaf. Most of well-developed leaves reach 5-7 mm long, while smaller shoots may have leaves up to $4 \mathrm{~mm}$ only. Leaf width in compression reaches $0.7 \mathrm{~mm}$, but

Figs. 16. Shoots of Palaeocampylopus buragoae Ignatov \& Shcherbakov: A, B, C, J- from PIN no. 5328/1; M, $\mathrm{N}, \mathrm{O}$ - from 5328/2. + indicate that specimen is not shown in photographs. Scale bar $10 \mathrm{~mm}$ for all.

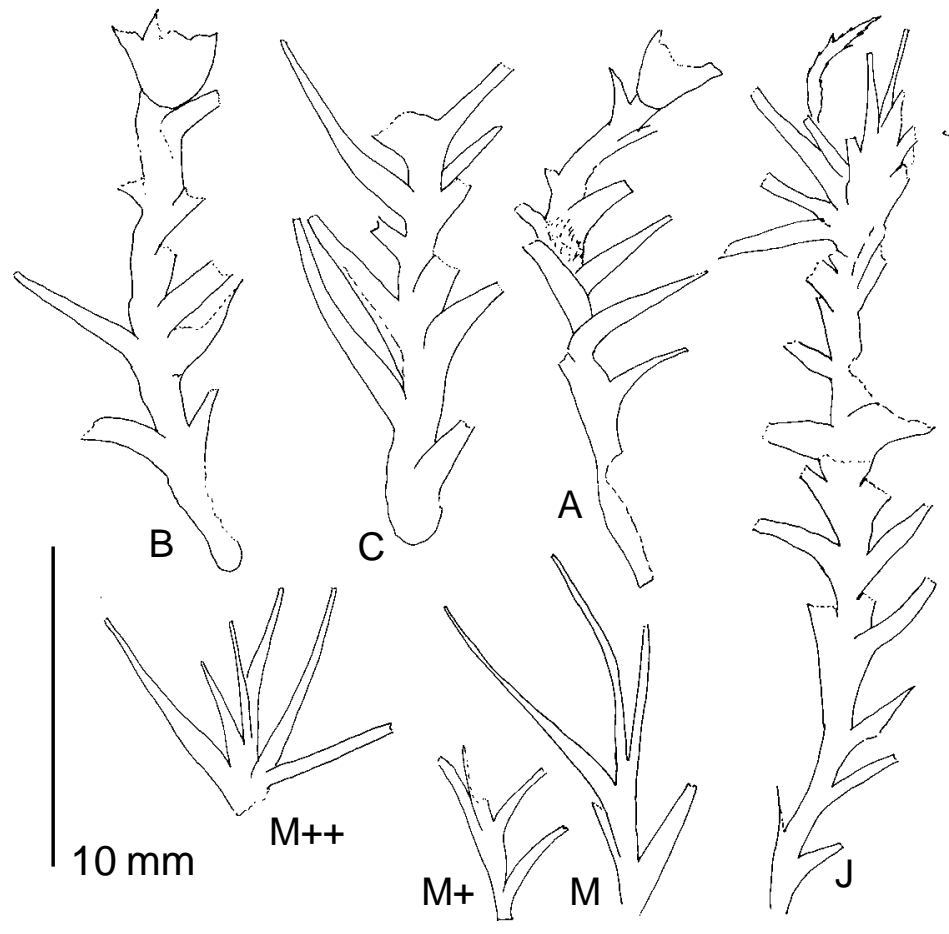

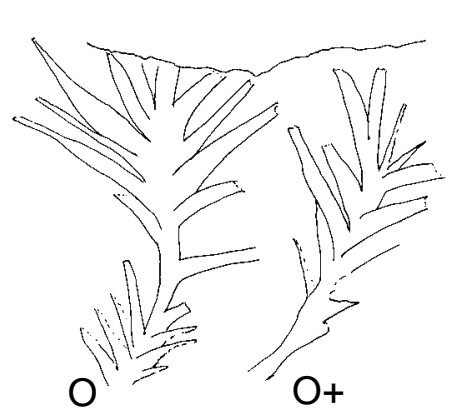

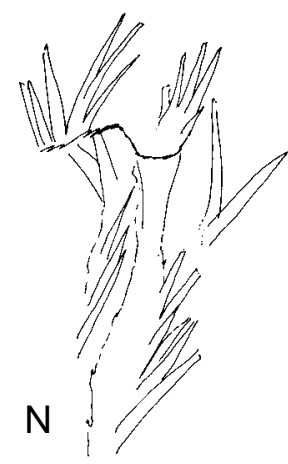




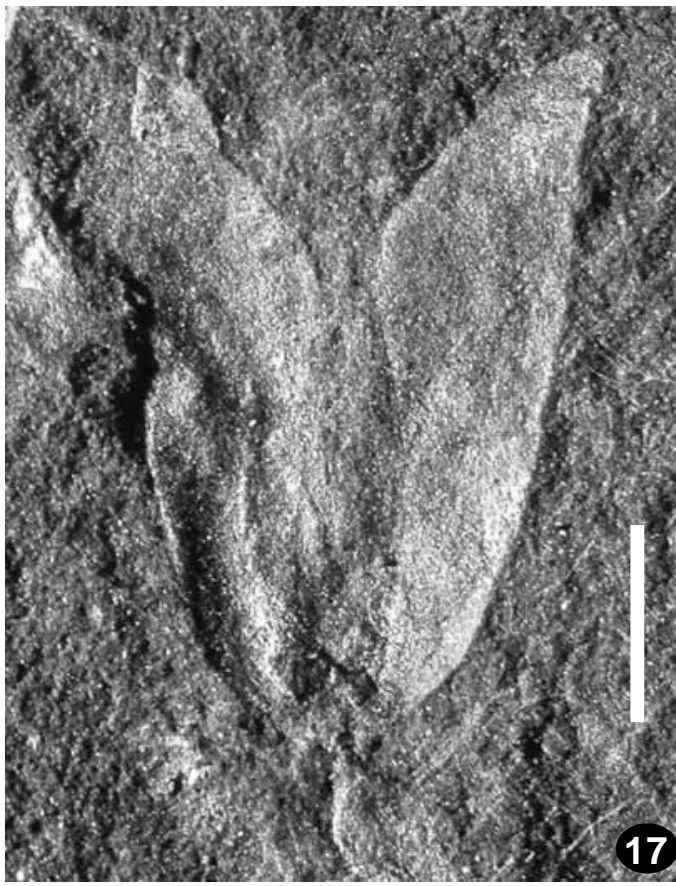

Figs. 17. Perigonial leaves (?) of Palaeocampylopus buragoae Ignatov \& Shcherbakov (?) (from PIN no. 5328/4). Scale bar $1 \mathrm{~mm}$.

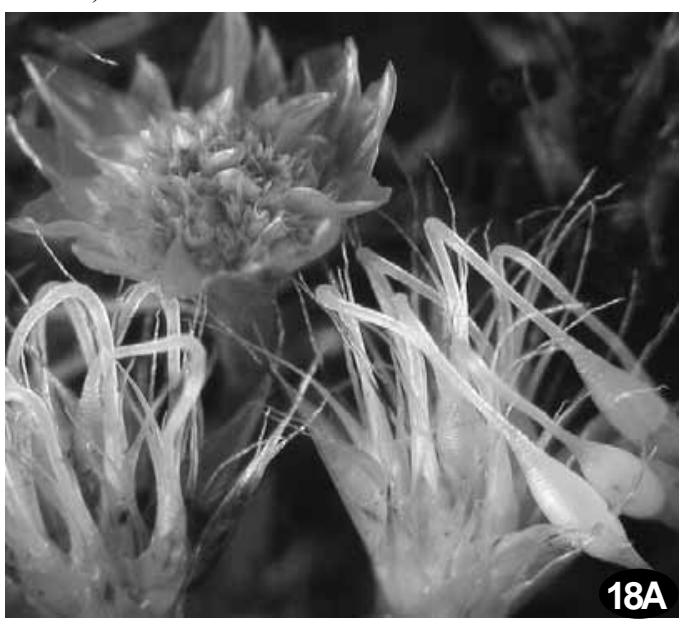

Figs. 18. Extant Campylopus: A-B - Campylopus umbellatus (Arn.) Paris. A (photo taken by Ms C. King and provided by B.C. Tan at Singapore Botanic Gardens): male (behind) and female (in front) inflorescences [i.e. gametangia surrounded by perigonial and perichaetial leaves]; B (New Guinea, Streimann, 24782, $\mathrm{MHA}^{1}$ ): male inflorescence; C-E - C. introflexus (Hedw.) Brid. (Kaliningrad Prov., Razgulyaeva, 2.IV.2000, MHA): C: leaf; D: habit, dry; E: leaf cross section. Scales: $2 \mathrm{~mm}$ for B-D; $100 \mu \mathrm{m}$ for $\mathrm{E}$.

${ }^{1}$ - Herbarium of the Main Botanical Garden of Russian Academy of Sciences this dimension should be assumed as a compression of an essentially tubulose or concave-tubulose structure. The costa is unseen in leaves as it was most likely very broad (similar to modern Campylopus or Polytrichum). In few cases a line along the leaf length is visible (e.g. Fig. 11) which possibly indicates one of leaf margins overlapping the rest of the flattened tubulose leaf. If this explanation is correct, then the margin is entire.

Being ca. $0.5 \mathrm{~mm}$ in diameter in the proximal leaf portion, the upper part is much narrower and linear-subulate, not exceeding 100(-200) $\mu \mathrm{m}$ wide. In upper leaves of plants that are interpreted here as female, their subulate part may constitute no less than $3 / 4$ of total length.

The longitudinal striation is seen in some places in the better preserved counterparts. It is quite likely that the width between the striae, 9$10 \mu \mathrm{m}$, may be interpreted as the cell width of dorsal epidermis or width between ridges similar to that occurring on abaxial costa surface in many Campylopus species (cf. Fig. 18).

Terminal cup-like structures (Figs. 1-5) are up to $3 \mathrm{~mm}$ high and $3.5 \mathrm{~mm}$ wide. Their preservation does not allow to define with certainty the shape of bracts, but outlines indicate that 2 or 3 triangular bract ends occur from one side. These

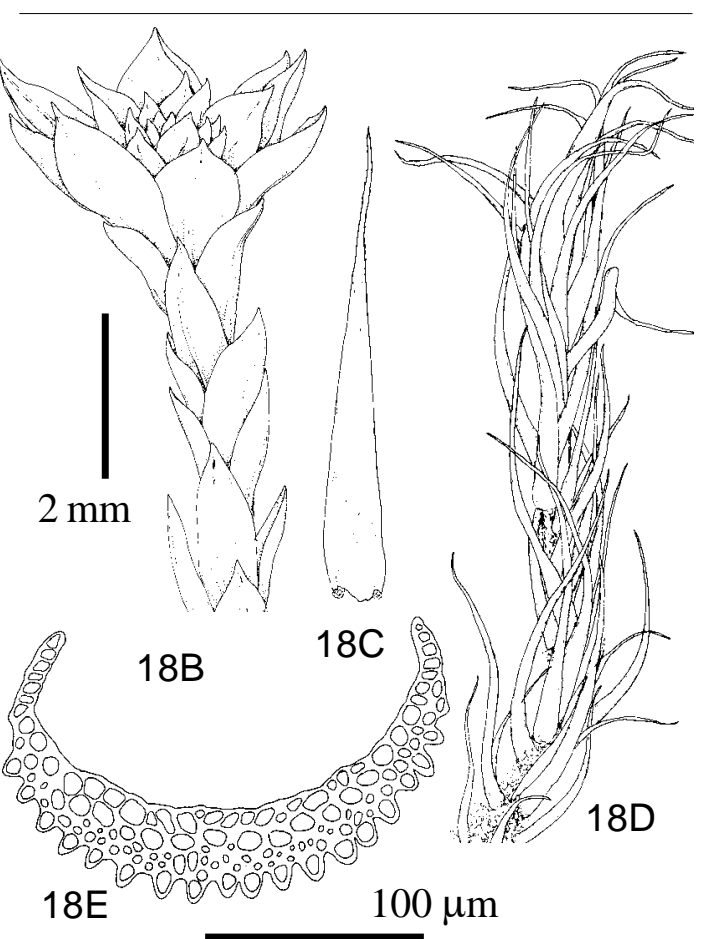


putative perigonial leaves probably were very closely appressed to each other, with no visible traces of borders between them (this is a common case in perigonial leaves of Polytrichum).

One imprint (Fig. 17) is considered as a possible perigonial structure because of similar texture, shape and approximately the same size (4.8 $\mathrm{mm}$ long, $3 \mathrm{~mm}$ wide), although it was found separately with no connection to another part that may be attributable to moss. This specimen is rather cylindric than cup-like which is characteristic of other terminal 'perigonia'. This difference however may be explained by just premature state of the male gametangia and correspondingly of the leaves surrounding them.

\section{PLANT DESCRIPTION}

Palaeocampylopus buragoae Ignatov \& Shcherbakov, genus et species nov. Figs. 1-16.

Generic diagnosis: Upper leaves aggregated in cup-like structures; leaves lanceolate to subulate, tubulose; costa indistinctly delimited from lamina in most of leaf length.

Specific diagnosis: Stems to $25 \mathrm{~mm}$ long, leaves, (4-)5-9 mm long, 0.4-0.7 $\mathrm{mm}$ wide below, gradually tapered to apex to acuminate, in subulate upper portion $0.1-0.2 \mathrm{~mm}$ wide. Terminal cup-like rosettes of presumably perigonial leaves to $5 \mathrm{~mm}$ long and $4 \mathrm{~mm}$ wide.

Description: Stem up to $25 \mathrm{~mm}$ long, with leaf bases up to $1.2 \mathrm{~mm}$ wide. Branching none. Shoots moderately densely foliate. Leaves polystichous, erect to patent (deviating from stem at 20-70 $\left(-100^{\circ}\right),(4-) 5-9 \mathrm{~mm}$ long, 0.4-0.7 mm wide below, gradually tapered to apex to acuminate, in subulate upper portion $0.1-0.2 \mathrm{~mm}$ wide at the distance of upper $1 / 3-1 / 2$ of leaf length, concave proximally and tubulose distally or plusminus tubulose throughout. Perigonial leaves tightly crowded at stem apex, shorly triangular, 3-5 $\mathrm{mm}$ long and with broad base, forming cuplike structures 3-4 $\mathrm{mm}$ in diameter.

Holotype: Russian Far East, Sea of Japan, Russky Island, ca. $43^{\circ} 00^{\prime} \mathrm{N} 131^{\circ} 50^{\prime} \mathrm{E}$ ); Lower Permian (Kungurian, lower Pospelovo Formation), collected in 2008 by Shcherbakov et al.; PIN no. 5328/1-B. Figs. 1, 2, 3, 4 (counterpart), 9, 16 (in all cases marked as B).

Other specimens: same age, locality and collcectors as for holotype, PIN no. 5328/1-6.
Distribution: Russky Island (see characteristics of locality).

Etymology: The generic epithet denotes our belief that cup-like structures are formed by perigonial leaves. The species is named in honour of Valentina I. Burago, a paleobotanist (Primorye Prospecting and Mapping Geological Expedition, Vladivostok) who first reported mosses from the Pospelovo Formation of Russky Island.

Differentiation. Permian mosses described before from Angaraland and Subangaraland (Neuburg, 1960; Fefilova, 1978; Meyen \& Gomankov, 1987; Ignatov, 1990), had mostly rather broad leaves, except for Arvildia and Viledia, but these plants were much smaller (leaves shorter than $1 \mathrm{~mm}$ ) and characterized by specific laminal areolation. For the latter genus the only one incomplete leaf was found (Ignatov, 1990).

Also, the conspicuous perigonial or similar structures were never observed in Palaeozoic and Mesozoic moss collections, though some possess sporophytes (Konopka et al., 1997, 1998).

\section{DISCUSSION}

Permian mosses of Angaraland described by Neuburg (1960) and Fefilova (1978) have mostly broad leaves with a distinct costa and border, resembling modern species of Mnium or Plagiomnium. The habit of the latter especially agrees with Intia, the fossil genus previously reported from the Lower Pospelovo Formation of the Russky Island (Burago in Meyen, 1982). Two other fossil genera, Uskatia Neub. and Polyssayevia Neub., recorded from synchronous or younger (Middle to Upper Permian) deposits in other parts of Primorye (Eliseeva \& Radchenko, 1964; Burago in Meyen, 1982), are somewhat similar to Palaeocampylopus, especially to shoots with a relatively short leaves gradually tapering from broadened bases (e.g. Figs. 8-10, 13-14). However, the leaves of these two genera have an acute rather than subulate upper part, and are shorter and wider $(2.6-4 \times 0.5-1.3 \mathrm{~mm}$ in Uskatia conferta Neub., 3.3-5.0 $\times 2-3.4 \mathrm{~mm}$ in Polyssaievia spinuliforlia (Zasessky) Neub.). In addition, they have a multistratose costa ca. $100 \mu \mathrm{m}$ wide that could unlikely be indiscernible in material with the present kind of preservation.

Merceria augustica Smoot \& T.N. Taylor from the Permian of Gondwanaland (Antarctic) 
was a rather large plant known mostly by a series of cross sections with excellent preservation of cell structure, but without any evidence of plant habit and leaf length, the leaves being $0.5-2.5$ mm wide and $1 / 6$ to $1 / 2$ of their width was occupied by the costa (Smoot \& Taylor, 1986).

As modern Polytrichum is quite similar to Palaeocampylopus, it would be worthy to discuss fossil taxa compared with the former. The best fossil material of both sporophytes and gametophytes of unequivocal Polytrichaceae, Eopolytrichum antiquum Konopka et al., is known from the Late Cretaceous (Konopka et al., 1997). This material represents capsules and anatomically preserved leaves with typical for the family structure of lamellae. The form-genus Polytrichites E. Britton was established from the Upper Miocene (Latah Formation, Washington State, U.S.A.) to accommodate one fossil plant similar to Polytrichum, Polytrichites spokanensis E. Britton in Knowlton. It was described by just one shoot $2 \mathrm{~cm}$ long with leaves $3-4 \mathrm{~mm}$ long (Knowlton, 1926). The stem has one branch appearing from its middle, which is an unusual case in Polytrichum (and most genera of the family), although in some other genera the branching occurs regularly, e. g. in Dendroligotrichum, and also in Pogonatum urnigerum. Another dissimilarity with Polytrichum is the size, which is too small for this genus. Steere (1946) suggested to extend the concept of the genus and include all the Polytrichales that can't be attributed to the extant genera. In practice this would be a difficult task, because the higher taxomonic units in mosses are usually more difficult to key out than the lower ones. In this light, the circumscription 'Polytrichales that do not fit modern genera' is not practical at all: it seems that there are no grounds to reject the attribution of the type species of Polytrichites to a number of Polytrichaceae genera, as well as to some members of Pottiaceae, Dicranaceae, Ptychomitriaceae and Grimmiaceae. Not surprising that the genus was almost unused, and only one more species was placed in it, Polytrichites aichiensis Yasui, from the Upper Tertiary of Central Japan (Yasui, 1928). The material of the latter was represented by stem transverse section, showing complex anatomy that is known for mosses only in Polytrichaceae.
Muscites polytrichaceus Renault et Zeiller, despite the species epithet, has very little in common with Polytrichaceae: plants have remote leaves $1.0-1.5 \mathrm{~mm}$ long, ovate, with a distinct narrow costa. A resemblance to Rhizogonium (Jovet-Ast, 1967) would be more appropriate.

Among modern groups, the superficial similarity can be traced to many acrocarpous moss families, but the most conspicuous cup-like perigonial leaves are known in Polytrichaceae, e.g. Polytrichum and Polytrichastrum, and some Dicranaceae, e.g. Campylopus (Fig. 18). Both these families are appropriate for comparison due to overall size (leaves up to 6-9 $\mathrm{mm}$ long are not common in modern mosses, usually they are shorter than $5 \mathrm{~mm}$ ), as well as to the broad costa filling more than half leaf width, which makes it indistinct in imprints. The abaxial costa in In Campylopus commonly has some ridge-like structures (Fig. 18) that make its surface striate, with the distance between striae almost equal to those observed in Palaeocampylopus (Fig. 15). The abaxial costa in Polytrichaceae also may exhibit sometimes certain striation.

At the same time, Polytrichaceae have a few characters that make their affinity with Palaeocampylopus somewhat less probable comparatively to Campylopus. The leaf shape, and especially its narrowly subulate upper parts agree with Campylopus much better than with Polytrichaceae species where leaves are stiff, more broad almost up to its apex, and usually have more strong differentiation into limb and sheathing base, while the leaf of Palaeocampylopus is rather gradually tapered upwards. In return, the perigonial leaves in Polytrichum, are more strongly specialized, tightly appressed to each other, making their rosettes thin and seamless, whereas in Campylopus they are usually not so conspicuously differentiated, although some of them admit compression up to the shape of Palaeocampylopus (Fig. 18).

Finally, it is worthy to note that 'perigonia' may be interpreted in a totally different way. They can be compared, for example, with terminal cuplike structures bearing gemmae in Tetraphis. The further comparison is not necessary, as the modern representatives of this ancient genus have small ovate leaves with a conspicuous narrow 
costa. However, a possibility that 'perigonia' in Palaeocampylopus may be a structure of a different function should also be kept in mind.

\section{ACKNOWLEDGEMENTS}

We are much indebted to our colleagues V.I. Burago, E.B. Volynets, S.A. Shorokhova and E.V. Bugdaeva, paleobotanists from Vladivostok, who kindly facilitated the 2008 field work of the PIN team in South Primorye and provided valuable information on localities and plants. We thank Photo of Campylopus umbellatus (Fig. 18A) taken by Ms C. King and provided by Dr. B.C. Tan at Singapore Botanic Gardens. The work was partly supported by RFBR 07-04-00013, 10-0401713.

\section{LITERATURE CITED}

[CHUMAKOV, N.M. \& M.A. ZHARKOV] ЧУМАKOB H.M., М.А.ЖАРКОВ 2002. Климат во время пермо-триасовых перестроек. 1. Климат ранней перми. - [Climate during Permian-Triassic biosphere reorganizations, Article 1: Climate of the Early Permian] Стратиграфия. Геол. Корреляция [Stratigrafiya. Geologicheskaya Korrelyatsiya] 10(6): 62-81 [English translation: 10: 586-602].

[ELISEEVA V.K. \& G.P. RADCHENKO] ЕЛИСЕЕВА В.К., Г.П. РАДЧЕНКО. 1964. Стратиграфия пермских континентальных и вулканогенных образований Южного Приморья. - [Stratigraphy of Permian continental and volcanogenic formations of South Primorye] Tpydbl ВСЕГЕИ [Trudy Vsesoyuz. Nauch.-Issled. Geol. Inst.] 107: $31-52$.

[FEFILOVA, L.A.] ФЕФИЛОВА Л.А.1978. Листостебельные мхи перми Европейского Севера СССР. - [Permian mosses of European North of USSR] Leningrad, Nauka [Л., Наука]. $120 \mathrm{pp}$.

[GOMANKOV, A.V. \& S.V. MEYEN] ГОМАНЬКОВ, А.В., С.В.МЕЙЕН 1987. Татариновая флора (состав и распространение в поздней перми Евразии). - [Tatarina flora (composition and distribution in the Late Permian of Eurasia)] Труды Геол. инст. АН СССР [Trudy Geol. Inst. Akad. Nauk SSSR] 401: 1-174.

HANKARD, F., J.-P. COGNÉ, X. QUIDELLEUR, A. BAYASGALAN \& P. LKLAVADORJ 2007. Paleomagnetism and $\mathrm{K}-\mathrm{Ar}$ dating of Cretaceous basalts from Mongolia. - Geophys. J. Int. 169: 898-908.

IGNATOV, M.S. 1990. Upper Permian mosses from the Russian Platform. - Palaeontographica Abt. B, 217: 147-189 + Pl. 1-9.

JOVET-AST, S. 1967. Bryophyta. -In: Boureau, E. (ed.) Traité de Paléobotanique, Paris, 2: 17-186.

KNOWLTON, F.H. 1926. Flora of the Latah formation of Spokane, Washington and Coeur d'Alene, Idaho. - U.S.Geol. Surv. Prof. Paper 140: $17-81+$ pl. 8-31.

KONOPKA, A.S., P.S. HERENDEEN, G.L. SMITH MERRILL \& P.R. CRANE 1997. Sporophytes and gametophytes of Poly- trichaceae from the Campanian (Late Cretaceous) of Georgia, U. S. A. - Int. J. Plant Sci. 158(4): 489-499.

KONOPKA, A.S., P.S. HERENDEEN \& P.R. CRANE 1998. Sporophytes and gametophytes of Dicranaceae from the Santonian (Late Cretaceous) of Georgia, USA. - Am. J. Bot. 85(5): 714-723.

KOTLYAR G.V., G.S. BELYANSKY, V.I. BURAGO, A.P. NIKITINA, YU.D. ZAKHAROV \& A.V. ZHURAVLEV 2006. South Primorye, Far East Russia - a key region for global Permian correlation. - J. Asian Earth Sciences 26: 280293.

LIGNIER, O. 1914. Sur une mousse houillère à structure conservee. - Bull. Soc. Linnéenne Normandie, ser. 6, 7: 128.

[MARKEVICH, P.V. \& YU.D. ZAKHAROV (eds.)] MAPКЕВИЧ П.В., Ю.Д. ЗАХАРОВ 2008. Триас и юра Сихотэ-Алиня. Книга 2. Вулканогенно-осадочный комплекс, палеобиогеография. - [Triassic and Jurassic of Sikhote-Alin. Vol.2. Volcano-sedimentary assemblage, paleobiogeography] Владивосток, Дальнаука [Vladivostok, Dal'nauka ], $300 \mathrm{pp}$.

MEYEN, S.V. 1982. The Carboniferous and Permian floras of Angaraland (a synthesis). - Biol. Mem. 7: 1-110.

[NEUBURG, M.F.] НЕЙБУРГ М.Ф. 1960. Листостебельные мхи из пермских отложений Ангариды. - [Mosses from the Permian of Angaraland] Trudy Geol. Inst. Akad. Nauk SSSR 19: 1-104 + $78 \mathrm{pl}$.

REES, P.McA., M.T. GIBBS, A.M. ZIEGLER, J.E. KUTZBACH \& P.J. BEHLING 1999. Permian climates: evaluating model predictions using global paleobotanical data. Geology 27: 891-894.

RENAULT, B. \& R. ZEILLER 1885. Sur des Mousses de l'époque houillère. - Compt. Rend. Hebd. Séanc. Acad.Sci. (Paris) 100: 660-662.

RENAULT, B. \& R. ZEILLER 1888. Études sur les terrain houiller de Commentry. Livre deuxième. Flore fossile. - Imprimateur Théolier and Cie, St. Étienne, pp. 3-366.

SMOOT, E.L. \& T.N. TAYLOR 1986. Structurally preserved fossil plants from Antarctica. II. A Permian moss from the Transantarctic Mountains. - Am. J. Bot. 73: 1683-1691.

STEERE, W.C. 1946. Coenozoic and mesozoic bryophytes of North America. - Amer. Midland Nat. 36: 298-324.

[TASHCHI, S.M. \& V.I. BURAGO] ТАЩИ C.M., B.M. БУРАГО 1974. Литологическо-палеофлористические характеристики перми Южного Приморья. - [Lithological-paleofloristic characteristics of the Permian of South Primorye] Советская геология [Sovetskaya Geologiya] 9: 40-48.

THOMAS, B. A. (1972) A probable moss from the Lower Carboniferous of the Forest of Dean, Gloucestershire. - Ann. Bot. 36: $155-161$.

TOWNROW, A. (1959) Two Triassic bryophytes from South Africa. - J. South African Botany. 25: 1-22.

YASUI, K. 1928. Studies of the structure of Lingite, Brown Coal, and bituminous Coal of Japan. - J. Fac. Sci. Imp. Univ. Tokyo, Sect 3 Botany I, 4: 381-468, pl. 9-24+ fig. 22 
ZAKHAROV YU.D., J.-G. SHA, A.M. POPOV, P.P. SAFRONOV, S.A. SHOROCHOVA, E.B. VOLYNETS, A.S. BIAKOV, V.I. BURAGO, V.G. ZIMINA \& I.V. KONOVALOVA 2009. Permian to earliest Cretaceous climatic oscillations in the eastern Asian continental margin (SikhoteAlin area), as indicated by fossils and isotope data. $-G F F$ 131: $1-23$.
[ZIMINA, V.G.] ЗИМИНА В.Г. 1977. Флора ранней и начала поздней перми Южного Приморья. - [Flora of the Early and Earlier Late Permian of South Primorye] M., Наука [Moscow, Nauka], $127 \mathrm{pp}$.

ZIMINA, V.G. 1997. Late Paleozoic flora of South Primorye and some problems of phytogeography. - Mém. Géologie (Lausanne) 30: 89-108. 